\section{Modified Microassay for Serum Nitrite and Nitrate}

BioTechniques 20:390-394 (March 1996)

Nitric oxide (NO) is produced in mammalian cells by one of three broad classes of nitric oxide synthase (NOS) (10). Large amounts of NO are generated by the cytokine-inducible isoform of NO synthase (iNOS) and have been implicated in cytotoxicity or cytostasis of activated macrophages toward parasites and tumors, in the pathology of septic shock, and in the suppression of cardiac function (10). Thus, assaying NO rapidly and efficiently in various fluids is of critical importance. High-output NO production by cells or its accumulation in biological solutions has been assayed in various ways (1-5,7-9,11). The simplest assay methods for relatively large amounts of NO in biological fluids have relied on the reaction of $\mathrm{NO}$ in aqueous solutions to form nitrite $\left(\mathrm{NO}_{2}{ }^{-}\right)$and nitrate $\left(\mathrm{NO}_{3}{ }^{-}\right)(1,3,4,9,11)$. In urine and plasma, $\mathrm{NO}$ is found primarily as $\mathrm{NO}_{3}^{-}$, but $\mathrm{NO}_{2}^{-}$can be assayed more easily by colorimetric diazotization (Griess reaction; References $1,3,4$ and 11). Upon reduction with metallic cadmium $(\mathrm{Cd})(3,4,11)$, or enzymatically by means of bacterial nitrate reductase $(1,2), \mathrm{NO}_{3}{ }^{-}$is converted to $\mathrm{NO}_{2}{ }^{-}$and can then be detected by the Griess reaction.

Quantitation of $\mathrm{NO}_{2}{ }^{-}$and $\mathrm{NO}_{3}{ }^{-}$in serum using bacterial nitrate reductase followed by the Griess reaction can be expensive and requires standardization of different batches of the enzyme (2). As currently implemented, reduction on $\mathrm{Cd}$ is cumbersome and time-consuming for many samples and may involve complex apparatus setup, as is the case with semi-automated nitrate analyzers (3). The method for Cd-mediated reduction of $\mathrm{NO}_{3}{ }^{-}$to $\mathrm{NO}_{2}^{-}$described by Hegesh and Shiloah (4) and Shi et al. (11) is inexpensive, but requires packing of toxic $\mathrm{Cd}$ shavings into columns, thus necessitating sample volumes greater than $100 \mu \mathrm{L}$. This report describes a modification of these protocols that is suitable for rapid, quantitative and inexpensive determination of serum $\mathrm{NO}_{2}{ }^{-}$and $\mathrm{NO}_{3}{ }^{-}$in samples containing as little as $10 \mu \mathrm{L}$ of serum. Furthermore, toxicity is reduced since granulated $\mathrm{Cd}$ instead of $\mathrm{Cd}$ shavings is used.

Normal rat serum was obtained from Life Technologies (Gaithersburg, MD, USA). Alternatively, C57BL/6J x SV129 mice (6) were sacrificed and blood obtained by cardiac puncture. Following a $30-$ min incubation on ice, the blood samples were centrifuged and the supernatant (serum) was removed for further processing. To reduce $\mathrm{NO}_{3}{ }^{-}$ to $\mathrm{NO}_{2}{ }^{-}, \mathrm{Cd}$ filings (0.4-0.7 g/filing; Fluka Chemical, Ronkonkoma, NY, USA), one per sample to be assayed, were placed into 1.5 -mL Eppendorf ${ }^{\circledR}$ microcentrifuge tubes (Brinkmann Instruments, Westbury, NY, USA). The filings were washed as follows: water $(2 \times 1 \mathrm{~mL}) ; 0.1 \mathrm{M} \mathrm{HCl}(2 \times 1 \mathrm{~mL}) ; 0.1$ $\mathrm{M}$ ammonium hydroxide, $\mathrm{pH} 9.6$ ( $2 \times 1$ $\mathrm{mL}$ ). Between washes, the samples were vortex mixed and rotated endover-end for $10 \mathrm{~min}$, and each Cd filing was distributed to a separate microcentrifuge tube. Each serum sample
(10-50 $\mu \mathrm{L}$ ) was brought up to $200 \mu \mathrm{L}$ with water, and then $10 \mu \mathrm{L}$ of $30 \%$ (wt/vol) $\mathrm{ZnSO}_{4}$ solution were added. The samples were vortex mixed, incubated at room temperature for $15 \mathrm{~min}$ and centrifuged for $5 \mathrm{~min}$. The resulting supernatants were added to the $\mathrm{Cd}$ containing microcentrifuge tubes and incubated at room temperature for overnight, rotating end-over-end. The samples were transferred to fresh microcentrifuge tubes and centrifuged again. 'The supernatants were subsequently assayed for $\mathrm{NO}_{2}^{-}+\mathrm{NO}_{3}^{-}$content. Nitrite was measured by the Griess assay $(3,4,11,12)$. Briefly, 100 $\mu \mathrm{L}$ Griess reagent (1\% sulfanilamide $/ 0.1 \%$ naphthylethylenediamine dihydrochloride/2.5\% $\mathrm{H}_{3} \mathrm{PO}_{4}$; Sigma Chemical, St. Louis, MO, USA) were added to $100 \mu \mathrm{L}$ of each of the above supernatants. The plates were read using a $V \max ^{\mathrm{TM}}$ microplate reader (Molecular Devices, Sunnyvale, CA, USA) at $550 \mathrm{~nm}$ against a standard curve of $\mathrm{NaNO}_{2}$. The values were corrected for

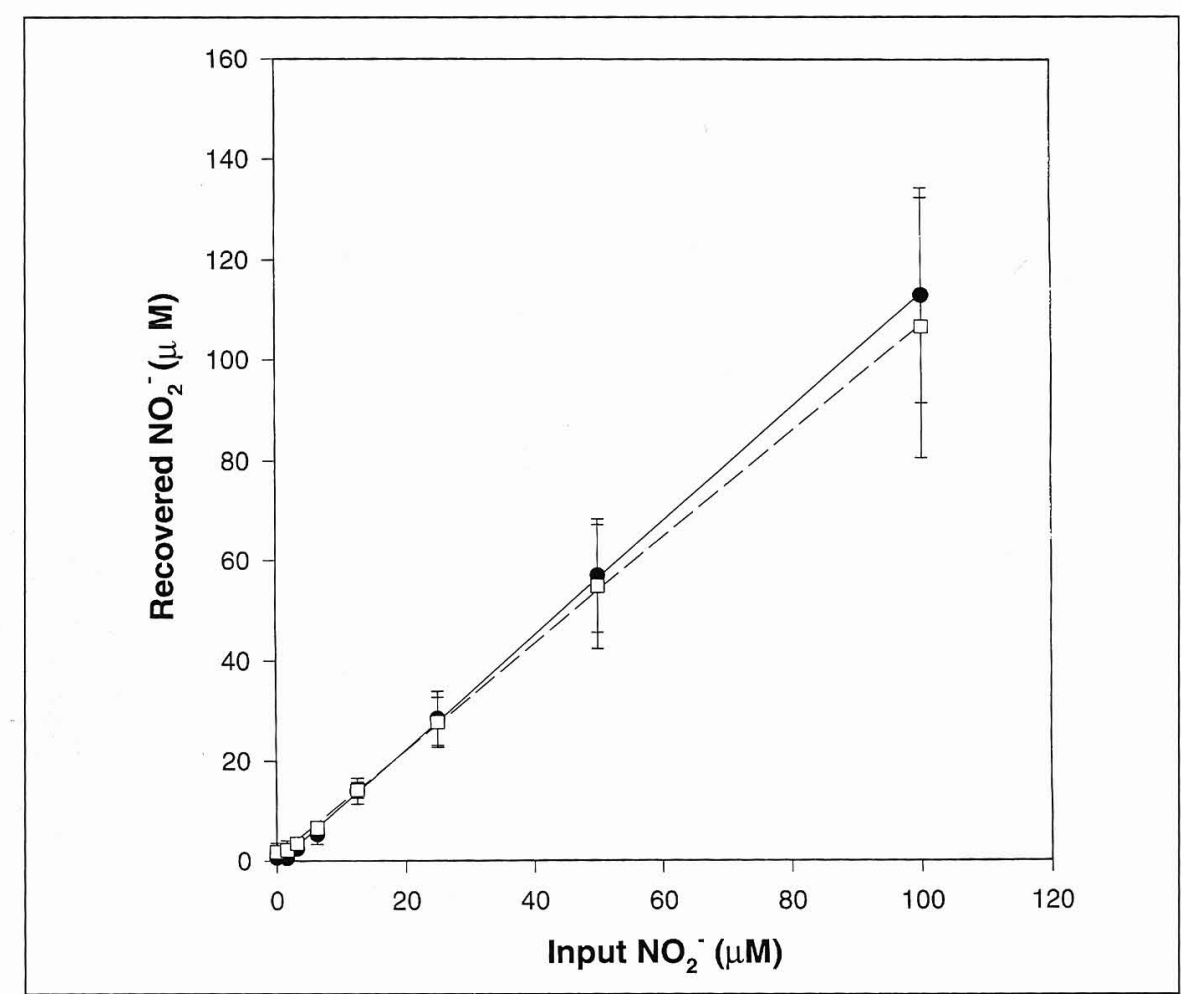

Figure 1. Recovery of $\mathrm{NO}_{2}{ }^{-}$after deproteination of serum. $190 \mu \mathrm{L}$ of the indicated concentrations of $\mathrm{NaNO}_{2}$ in water $(0,1.56,3.13,6.25,12.5,25,50$ and $100 \mu \mathrm{M})$ were incubated with $10 \mu \mathrm{L}$ of normal rabbit serum and then deproteinated (filled circles, solid line). Control samples contained the same concentrations of $\mathrm{NaNO}_{2}$ and $\mathrm{ZnSO}_{4}$, but did not contain serum and were not deproteinated (open squares, dashed line). After centrifugation of all the samples, the supernatants were assayed for $\mathrm{NO}_{2}{ }^{-}$by the Griess assay. Each point represents the mean \pm standard error of three separate experiments. Lines represent a linear regression analysis of recovered $\mathrm{NO}_{2}^{-}$vs. input $\mathrm{NO}_{2}^{-}$either with or without added serum. 
the $\mathrm{NO}_{2}^{-}+\mathrm{NO}_{3}{ }^{-}$content of water, and the recovery of $\mathrm{NO}_{2}^{-}$was calculated.

Previous reports have stated that NO in serum and urine is present predominantly as $\mathrm{NO}_{3}{ }^{-}$, not as $\mathrm{NO}_{2}{ }^{-}$(3). In accordance with this observation, no $\mathrm{NO}_{2}^{-}$was detected in normal rat serum samples prior to reduction by $\mathrm{Cd}$ (data not shown). The next parameter tested was whether addition of serum and deproteination affected the recovery of $\mathrm{NO}_{2}{ }^{-}$added exogenously to serum. Standard concentrations of $\mathrm{NO}_{2}^{-}$ $(1-100 \mu \mathrm{M})$ were assayed after the addition of water alone or after serum and $\mathrm{ZnSO}_{4}$, the deproteinating agent. Detection of $\mathrm{NO}_{2}^{-}$without serum and deproteination occurred with an efficiency of $113 \%$, as calculated from the slope of a regression line of input $\mathrm{NO}_{2}{ }^{-}$ vs. recovered $\mathrm{NO}_{2}^{-}$over a concentration range of $1-100 \mu \mathrm{M} \mathrm{NO}_{2}^{-}(n=21)$, while the detection of $\mathrm{NO}_{2}{ }^{-}$following addition of serum and deproteination occurred with an efficiency of $105 \%$ $(n=21)$ over the same range of $\mathrm{NO}_{2}{ }^{-}$ concentrations (Figure 1). The conversion of $\mathrm{NO}_{3}^{-}$to $\mathrm{NO}_{2}^{-}$mediated by $\mathrm{Cd}$ occurred with an efficiency of $104 \%$ (mean $\pm \mathrm{SEM} ; n=16$ ), taken across all concentrations tested (3-100 $\mu \mathrm{M}$; Figure 2). This occurred regardless of the exact weight of the $\mathrm{Cd}$ filings used (0.4-0.7 g; data not shown). Thus, the detection of $\mathrm{NO}_{2}^{-}$occurred with approximately the same efficiency whether $\mathrm{NO}_{2}^{-}$was added to serum or whether $\mathrm{NO}_{3}^{-}$was added and then reduced to $\mathrm{NO}_{2}{ }^{-}$by $\mathrm{Cd}$. Using the method described herein, I determined the concentration of $\mathrm{NO}_{2}^{-}+\mathrm{NO}_{3}^{-}$in C57BL/6J x SV129 mouse serum to be $51 \pm 10 \mu \mathrm{M}(n=30)$. When C57BL/6J x SV129 mouse serum was assayed by a previously described fluorometric method (9; courtesy of Dr. Jane Connor, Searle-Monsanto, St. Louis, MO, USA), the results were essentially identical $(49 \pm 7 \mu \mathrm{M}[n=5])$. Syngeneic mice lacking the gene for transforming growth factor- $\beta 1$, which profoundly suppresses iNOS expression in vitro (12), had fourfold elevated levels of serum $\mathrm{NO}_{2}^{-}+\mathrm{NO}_{3}^{-}$. This increase in systemic NO production could be inhibited by $N^{\mathrm{G}}$-monomethyl-L-arginine,

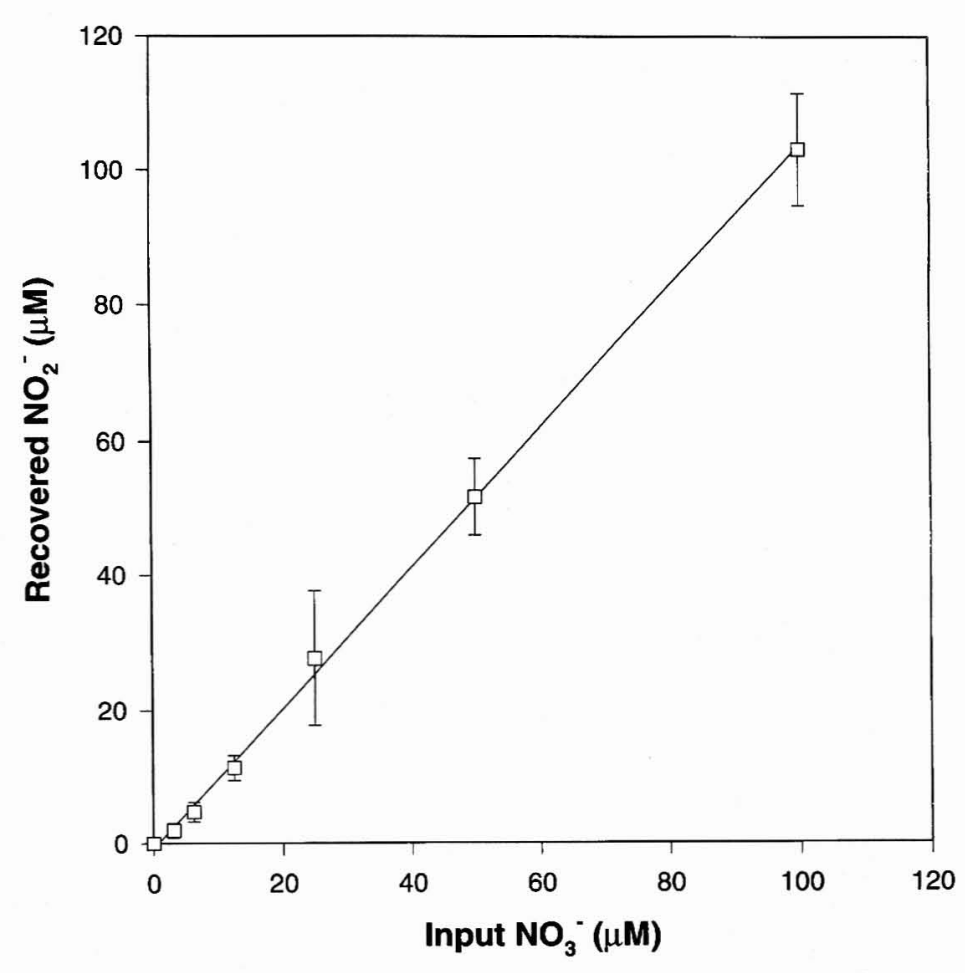

Figure 2. Conversion of $\mathrm{NO}_{3}{ }^{-}$to $\mathrm{NO}_{2}{ }^{-} .200 \mu \mathrm{L}$ of indicated concentrations of $\mathrm{NaNO}_{3}$ in water $(0,1.56$, $3.13,6.25,12.5,25,50$ and $100 \mu \mathrm{M}$ ) were subjected to reduction by Cd. After centrifugation, supernatants were assayed for $\mathrm{NO}_{2}{ }^{-}$by the Griess assay. Each point represents mean \pm standard error of three separate experiments. Lines represent a linear regression analysis of recovered $\mathrm{NO}_{2}^{-}$vs. input $\mathrm{NO}_{3}{ }^{-}$. 
an inhibitor of NOS activity (13).

This modification of the Cd-mediated reduction of $\mathrm{NO}_{3}{ }^{-}$to $\mathrm{NO}_{2}{ }^{-}$is accurate, reproducible and also rapid, as many samples can be assayed simultaneously. It does not require sophisticated apparatus or relatively large sample volumes. Finally, since granulated $\mathrm{Cd}$ instead of fine Cd shavings are used, there is a lower likelihood of inhaling small particles of $\mathrm{Cd}$ and thus a potentially lower toxicity to the researcher. As the study of NO and its physiologic and pathophysiologic effects develops, a quick, easy and inexpensive assay for serum NO levels is needed. The assay described herein should facilitate these studies.

\section{REFERENCES}

1.Bartholomew, B. 1984. A rapid method for the assay of nitrate in urine using the nitrate reductase enzyme of Escherichia coli. Food Chem. Toxic. 22:541-543.

2.Granger, D.L., J.B. Hibbs, Jr. and L.M. Broadnax. 1991. Urinary nitrate excretion in relation to murine macrophage activation: influence of dietary L-arginine and oral $\mathrm{N}^{\mathrm{a}}$ monomethyl-L-arginine. J. Immunol. 146: 1294-1302.

3.Green, L.C., D.A. Wagner, J. Glogowski, P.L. Skipper, J.S. Wishnok and S.R. Tannenbaum. 1982. Analysis of nitrate, nitrite, and $\left[{ }^{15} \mathrm{~N}\right]$ nitrate in biological fluids. Anal. Biochem. 126:131-138.

4.Hegesh, E. and J. Shiloah. 1982. Blood nitrates and infantile methemoglobinemia. Clin. Chim. Acta 125:107-115.

5.Hibbs, J.B., Jr., R.R. Taintor, Z. Vavrin and E.M. Rachlin. 1988. Nitric oxide: a cytotoxic activated macrophage effector molecule. Biochem. Biophys. Res. Commun. 157:87-94.

6.Kulkarni, A.B., C. Huh, D. Becker, A. Geiser, M. Lyght, K.C. Flanders, A.B. Roberts, M.B. Sporn, J.M. Ward and S. Karlsson. 1993. Transforming growth factor $\beta 1$ null mutation in mice causes excessive inflammatory response and early death. Proc. Natl. Acad. Sci. USA 90:770-774.

7.Lancaster, J.R., Jr. and J.B. Hibbs, Jr. 1990. EPR demonstration of iron-nitrosyl complex formation by cytotoxic activated macrophages. Proc. Natl. Acad. Sci. USA 87:12231227.

8.Malinski, T. and Z. Taha. 1992. Nitric oxide release from a single cell measured in situ by a porphyrinic-based microsensor. Nature 358:676-678.

9.Misko, T.P., R.J. Schilling, D. Salvemini, W.M. Moore and M.G. Currie. 1993. A fluorimetric assay for the measurement of nitrite in biological samples. Anal. Biochem. 214:11-16.

10.Nathan, C. 1992. Nitric oxide as a secretory product of mammalian cells. FASEB $\mathbf{J}$. 6:3051-3064.

11.Shi, Y., H. Li, C. Shen, J. Wang, S. Qin, R.
Liu and J. Pan. 1993. Plasma nitric oxide levels in newborn infants with sepsis. J. Pediatr. 123:435-438.

12.Vodovotz, Y., C. Bogdan, J. Paik, Q. Xie and C. Nathan. 1993. Mechanisms of suppression of macrophage nitric oxide release by transforming growth factor- $\beta$. J. Exp. Med. 178:605-613.

13.Vodovotz, Y., A.G. Geiser, L. Chesler, J.J. Letterio, A. Campbell, M.S. Lucia, M.B. Sporn and A.B. Roberts. Spontaneously increased production of nitric oxide and aberrant expression of the inducible nitric oxide synthase in vivo in the transforming growth factor- $\beta 1$ null mouse. J. Exp. Med. (In press).

Address correspondence to Yoram Vodovotz, Laboratory of Chemoprevention, National Cancer Institute, Bethesda, MD 20892, USA. Internet: vodovoty@dce41. nci.nih.gov

Received 24 July 1995; accepted 13 October 1995.

\section{Yoram Vodovotz}

National Cancer Institute Bethesda, MD, USA

Circle Reader Service No. 176

\section{Recovering DNA from Agarose Gels with Pumice}

BioTechniques 20:394-398 (March 1996)

A recent publication (2) and discussions in the Internet newsgroup bionet.molbio.methds-reagnts indicate that the use of glass slurry is still a popular method for purifying DNA from agarose gels. Many of the commercially available glass slurry preparations are based on the description of Vogelstein and Gillespie (4). In this communication, we present a modification of the Vogelstein and Gillespie technique that involves the use of pumice (5), instead of glass, as the DNA-binding agent. We have found the pumice preparation to be an inexpensive substitute for commercially available glass slurries in our instructional laboratories where students use large quantities in their learning experiences. Commercial preparations cost approximately $\$ 0.90$ to $\$ 1.00$ per extraction, compared to about $\$ 0.04$ per extraction for the pumice method.

Two different pumice sources were used with equal success. One source was Baker and Adamson pumice powder (code 2157; Lot No. E175; New York, NY, USA) and the other was Matheson, Coleman, Bell pumice stone, powdered (PX1980 L655; Norwood, OH, USA). A fine pumice suspension was prepared by combining 10 $\mathrm{g}$ pumice powder with $100 \mathrm{~mL} \mathrm{H}_{2} \mathrm{O}$ in a $250-\mathrm{mL}$ beaker and mixing with a magnetic stirrer till homogenous. The suspension was allowed to sit for 30 min to allow larger particles to sediment under unit gravity. The supernatant was carefully decanted to another beaker and allowed to sit for an additional $30 \mathrm{~min}$. The resulting supernatant, containing the fine (suspended) pumice particles, was decanted into two $50-\mathrm{mL}$ polypropylene centrifuge tubes and centrifuged for $5 \mathrm{~min}$ at 9000 $\mathrm{rpm}$ in an IEC Model B-20 centrifuge (Needham, MA, USA). The supernatant was removed with a pipet and discarded. The sedimented pumice was resuspended in $500 \mu \mathrm{L} \mathrm{H}_{2} \mathrm{O}$, transferred to a $1.5-\mathrm{mL}$ graduated microcentrifuge tube and centrifuged for $5 \mathrm{~min}$ at $14000 \mathrm{rpm}$ in an Eppendorf ${ }^{\circledR}$ Model 